\title{
Deleterious Impact of a Virulent Bacteriophage on Survival and Biocontrol Activity of Pseudomonas fluorescens Strain CHAO in Natural Soil
}

\author{
Christoph Keel, ${ }^{1}$ Zöhre Ucurum,, ${ }^{1}$ Patrick Michaux, ${ }^{1}$ Marc Adrian, ${ }^{2}$ and Dieter Haas ${ }^{1}$ \\ ${ }^{1}$ Laboratoire de Biologie Microbienne and ${ }^{2}$ Laboratoire d'Analyse Ultrastructurale, Université de Lausanne, $\mathrm{CH}-1015$ \\ Lausanne, Switzerland
}

Submitted 16 November 2001. Accepted 6 February 2002.

\begin{abstract}
Many biotic and abiotic factors affect the persistence and activity of beneficial pseudomonads introduced into soil to suppress plant diseases. One such factor may be the presence of virulent bacteriophages that decimate the population of the introduced bacteria, thereby reducing their beneficial effect. We have isolated a lytic bacteriophage (ФGP100) that specifically infects the biocontrol bacterium Pseudomonas fluorescens CHA0 and some closely related Pseudomonas strains. ФGP100 was found to be a doublestranded-DNA phage with an icosahedral head, a stubby tail, and a genome size of approximately $50 \mathrm{~kb}$. Replication of $\Phi$ GP100 was negatively affected at temperatures higher than $25^{\circ} \mathrm{C}$. $\Phi$ GP100 had a negative impact on the population size and the biocontrol activity of $P$. fluorescens strain CHA0-Rif (a rifampicin-resistant variant of CHA0) in natural soil microcosms. In the presence of $\Phi \mathrm{GP100}$, the population size of strain CHA0-Rif in soil and on cucumber roots was reduced more than 100 -fold. As a consequence, the bacterium's capacity to protect cucumber against a root disease caused by the pathogenic oomycete Pythium ultimum was entirely abolished. In contrast, the phage affected neither root colonization and nor the disease suppressive effect of a $\Phi$ GP100-resistant variant of strain CHA0-Rif. To our knowledge, this study is the first to illustrate the potential of phages to impair biocontrol performance of beneficial bacteria released into the natural soil environment.
\end{abstract}

Additional keywords: antifungal, Podoviridae, rhizosphere, root rot, soilborne pathogens.

Select strains of root-colonizing fluorescent pseudomonads can be used to promote plant growth and to suppress plant diseases caused by soilborne fungal pathogens. Following introduction into soil, the plant-beneficial performance of these bacteria relies largely on their ability to maintain stable populations and to be metabolically active in the rhizosphere. However, the sizes of introduced pseudomonad populations may decline considerably within a few weeks, and plant-beneficial activity often tends to be variable (Keel and Défago 1997). A variety of biological, chemical, and physical factors may affect

Corresponding author: C. Keel, Telephone: +41 21692 5636; Fax: +41 21 692 5635; E-mail: christoph.keel@lbm.unil.ch

Current address of Z. Ucurum: Institut für Mikrobiologie, ETH, CH-8092 Zürich, Switzerland. the persistence and the biological activity of beneficial pseudomonads in soil and in the rhizosphere. Among the biological factors, bacteriophages are potentially important, because they may have adverse effects on bacterial populations in soil (Elsherif and Grossmann 1996; Marsh and Wellington 1994).

Bacteriophages are ubiquitous in the environment and they are thought to be ecologically important by controlling bacterial numbers and activity, affecting composition and diversity of bacterial populations, and facilitating gene transfer between bacteria via transduction (Ashelford et al. 1999a, 2000; Fuhrman 1999; Marsh and Wellington 1994; Miller 2001; Williams et al. 1987). Specific phage-host interactions have been investigated in marine environments (Fuhrman 1999) and also, though to a lesser extent, in soil environments (Cresswell et al. 1992; Germida 1986; Herron and Wellington 1994; Marsh and Wellington 1994; PantasticoCaldas et al. 1992; Smit et al. 1996). In soil, phages are likely to be abundant in nutrient-rich habitats such as the rhizosphere (i.e., an ecological niche which can support high population densities of metabolically active bacteria). In a limited number of studies, populations dynamics of phages and their host bacteria in the rhizosphere were monitored in microcosms (Barnet 1980; O'Sullivan et al. 1990; Smit et al. 1996; Stephens et al. 1987) and, more recently, also in the field (Ashelford et al. 1999a, 2000).

Numerous studies document that phages capable of infecting fluorescent pseudomonads can be isolated from different environments (Ackermann 2001; Ashelford et al. 1999a; Bigby and Kropinski 1989; Campbell et al. 1995; Holloway and Krishnapillai 1975; Jensen et al. 1998; Krylov et al. 1989; Park et al. 2000; Stephens et al. 1987). Nevertheless, the ecological role of phages of fluorescent pseudomonads in soil and in the rhizosphere has received little attention. Relatively few studies have reported on interactions between phages and plant-beneficial fluorescent pseudomonads in these habitats (Ashelford et al. 1999a; O'Sullivan et al. 1990; Smit et al. 1996; Stephens et al. 1987). Potential effects of phages on the plant-beneficial activity of these bacteria have not been investigated.

Here, we report on the isolation and characterization of a lytic phage, $\Phi \mathrm{GP} 100$, that is specific for the plant-beneficial bacterium Pseudomonas fluorescens CHA0 and some closely related Pseudomonas strains. Strain CHA0 is an effective biological control agent which colonizes the roots of many crop plants and protects them against diseases caused by pathogenic fungi (Keel and Défago 1997; Voisard et al. 1994). The strain produces the antifungal polyketides 2,4-diacetylphloroglucinol (Phl) and pyoluteorin (Plt), which make major contributions to 
its disease-suppressive capacity (Haas et al. 2000; Keel and Défago 1997; Voisard et al. 1994). Our present study illustrates the negative impact of phage $\Phi$ GP100 on survival, root colonization, and disease-suppressive capacity of strain $\mathrm{CHA} 0$ in natural soil. We demonstrate that the deleterious effect of the phage can be countered by the use of a phage-resistant variant of strain $\mathrm{CHA}$.

\section{RESULTS}

\section{Morphology and genome of phage $\Phi$ GP100.}

A bacteriophage capable of infecting $P$. fluorescens strain CHA0 and its rifampicin-resistant derivative CHA0-Rif was isolated from soil and purified as described below. Electron micrographs showed that the phage, named ФGP100, had an isometric icosahedral head and a short noncontractile tail (Fig. 1). The average diameter of the head capsid measured between opposite apices was $97 \pm 5 \mathrm{~nm}(n=20)$ and the average length of the tail was $19 \pm 4 \mathrm{~nm}(n=7)$. Based on restriction analysis of extracted phage $\Phi$ GP100 DNA with a total of 17 enzymes (Fig. 2) and 14 enzyme combinations (data not shown), the genome size was estimated to be approximately $50 \mathrm{~kb}$. For instance, restriction with $\mathrm{NcoI}$ yielded 11 bands of $0.8,1.5,2.1$, $2.2,2.8,3.4,4.1,4.2,5.5,7.6$, and approximately $15 \mathrm{~kb}$, respectively (Fig. 2). The morphological characteristics and the relatively large genome consisting of double-stranded DNA are typical of the Podoviridae family (Ackermann 2001; van Regenmortel et al. 2000).

\section{Growth characteristics of phage ФGP100.}

Phage $\Phi$ GP100 produced clear plaques of approximately 2 to $3 \mathrm{~mm}$ in diameter on lawns of its bacterial host after incubation on nutrient agar (NA) for $24 \mathrm{~h}$ at $20^{\circ} \mathrm{C}$. The capacity of the phage to form plaques depended on the temperature prevailing during the infection period. Clear plaques were formed at 15 and $20^{\circ} \mathrm{C}$. Plaques were turbid with borders becoming frayed out at 25 and $28^{\circ} \mathrm{C}$. At temperatures equal to or higher than $30^{\circ} \mathrm{C}$, no plaques were formed. Plaque formation did not depend on the incubation temperature of the bacterial culture before phage contact $\left(20,25,30\right.$, and $35^{\circ} \mathrm{C}$ were tested), indicating that temperature affected phage replication rather than phage attachment to the bacterial surface. Based on single-step growth curve experiments using a Pseudomonas fluorescens $\mathrm{CHA} 0$ host culture grown at $20^{\circ} \mathrm{C}$ (Fig. 3), the phage had an estimated latent period of 90 to $100 \mathrm{~min}$ and a calculated burst size of approximately 24 particles per infected host cell. When the experiment was carried out at $30^{\circ} \mathrm{C}$, the initial titer slowly decreased (Fig. 3), thus confirming the adverse effect of elevated temperatures on the replication of the phage. Identical phage multiplication patterns were obtained when the rifampicin-resistant derivative CHA0-Rif was used as the host (data not shown).

Phage ФGP100 also was tested for sensitivity to heat, ultraviolet (UV) light, and chloroform, as recommended by Ackermann and associates (1978). Exposure of a phage lysate $\left(10^{8} \mathrm{PFU} / \mathrm{ml}\right)$ to temperatures of 20,30 , or $37^{\circ} \mathrm{C}$ for up to $24 \mathrm{~h}$ did not affect phage survival. $\Phi$ GP 100 resisted to $60^{\circ} \mathrm{C}$ for 10 min without significant loss of titer. However, prolonged exposure (>30 min) to this temperature or exposure to higher temperatures $\left(80^{\circ} \mathrm{C}\right)$ completely inactivated the phage. Exposure to a UV germicidal lamp at $15 \mathrm{~cm}(254 \mathrm{~nm})$ for $5,10,30$, or $60 \mathrm{sec}$ resulted in 14, 65, 56, and 78\% inactivation of the viable phage population, respectively. The phage was resistant to $10 \%$ (vol/vol) chloroform for at least 10 days.

\section{Host range of phage $\Phi$ GP100.}

The ability of phage $\Phi$ GP100 to propagate on different bacterial hosts is shown in Table 1 . Several mutants of $P$. fluorescens CHA0 tested were as sensitive to ФGP100, as was the wild type. For instance, exopolysaccharide-overproducing mucA mutants as well as gacS/gacA mutants, which are pleiotropically impaired in the production of a range of secondary metabolites and exoenzymes, were attacked by the phage (Table 1). ФGP100 appeared to have a very limited host range, because most of the other bacterial hosts tested, including different Pseudomonas spp. and a series of other gram negative bacteria, were resistant to the phage (Table 1).

However, out of a worldwide collection of 97 pseudomonads producing the antifungal metabolite Phl, 13 strains (i.e., Pf1, PINR2, PINR3, PGNR1, PGNR2, PGNR3, PGNR4, PGNL1, K93.25, K94.4, K94.5, K94.6, and K94.30) were sensitive to phage ФGP100 (Table 1). Interestingly, these strains are genotypically and phenotypically highly similar to strain $\mathrm{CHA}$. In addition to $\mathrm{Phl}$, they produce $\mathrm{Plt}$, another antifungal

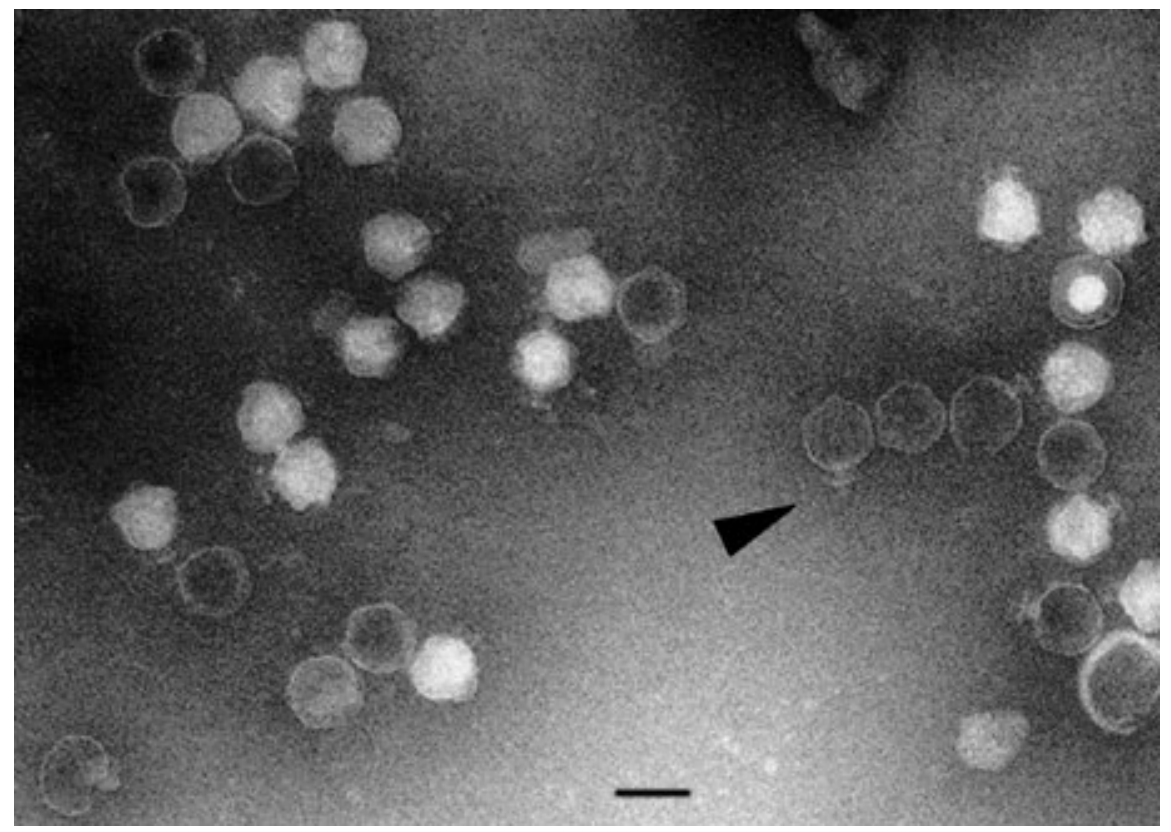

Fig. 1. Electron micrograph showing filled and empty icosahedral heads and the stubby tail (indicated by an arrow) of bacteriophage $\Phi$ GP100. Bar $=100 \mathrm{~nm}$. 
compound, and they cluster in the same amplified $16 \mathrm{~S}$ ribosomal DNA restriction analysis (ARDRA), randomly amplified polymorphic DNA (RAPD), and BIOLOG (carbon source utilization profiles) groups as does strain CHA0 (Keel et al. 1996; Ramette et al. 2001; Wang et al. 2001). Moreover, these strains reacted with an antibody raised against CHA0 cells (Troxler et al. 1997b) at the same low titer as did strain CHA0 (data not shown). Two additional $\mathrm{Phl}^{+} \mathrm{Plt}^{+}$pseudomonads (i.e., strains Pf-5 and PF), which cluster in the same ARDRA group as strain CHA0 but in different RAPD and BIOLOG groups (Keel et al. 1996; Wang et al. 2001), were sensitive only to 1,000 -fold-higher titers of the phage (Table 1) and only slightly cross-reacted with the CHA0 antibody (data not shown). The remaining $82 \mathrm{Phl}^{+} \mathrm{Plt}^{-}$pseudomonads clustering in a different ARDRA group (Keel et al. 1996) were resistant to the phage (Table 1) and showed no cross-reaction, even with high titers of the CHA0 antibody. In conclusion, phage ФGP100 is highly specific for P. fluorescens CHA0 and some very closely related Pseudomonas strains.

\section{Isolation of $\Phi$ GP100-resistant variants of $P$. fluorescens.}

Phage $\Phi$ GP100-resistant variants of $P$. fluorescens strains CHAO and CHA0-Rif were detected as distinct microcolonies that formed within 2- to 3-day-old clear plaques on the bacterial lawn. A total of 20 candidates per strain that remained resistant to the phage after repeated subculturing were selected for further analysis. The phage-resistant variants were indistinguishable from their parental strains in terms of growth, colony morphology, production of extracellular metabolites and enzymes, in vitro inhibitory activity, and cross-reaction with the CHA0 antibody (data not shown). A phage-resistant variant of strain CHA0-Rif (i.e. CHA0-Rif- $\Phi$ R) was chosen for the biocontrol experiments described below.

The occurrence of phage-insensitive cells might be due to the possible formation of lysogens; therefore, phage-resistant variants were tested for spontaneous or UV-induced release of phage particles as described below. However, all attempts to produce any detectable phage particles from phage-resistant cells failed. In addition, DNA from phage-resistant cells did not hybridize to digoxigenin-labeled DNA from phage ФGP100 (Fig. 4), indicating that there was no phage DNA present in these cells. These findings suggest that $\Phi$ GP100 is a lytic rather than a temperate phage and that resistance to the phage was a result of mutations in the host strains CHAO and CHA0-Rif. Experiments carried out to demonstrate transduction of auxotrophic mutants of strain CHA0 (Troxler et al. 1997a) with phage $\Phi$ GP100, previously grown on the prototrophic parental strain, failed.

\section{Phage $\Phi$ GP100 affects survival of $P$. fluorescens CHA0-Rif in natural soil.}

To investigate the interactions between $\Phi G P 100$ and its host in a natural environment, the phage and strain $\mathrm{CHA0}$ Rif were coinoculated or added individually to soil microcosms. In the absence of $\Phi$ GP100, the numbers of CFU of strain CHA0-Rif slowly declined from $\log _{10} 7.9$ initially to $\log _{10} 6.7$ at the end of the 8-day experiment (Fig. 5). In the presence of the phage at a multiplicity of infection (m.o.i.) of 1.6, CFU counts of CHA0-Rif rapidly dropped by three orders of magnitude to $\log _{10} 4.9$ (Fig. 5). From day 2 after addition to soil, the population of CHA0-Rif started slowly to recover from the phage attack (Fig. 5), possibly because a fraction of the bacterial cells became resistant to the phage (see below). In the presence of its host, phage ФGP100 attained significantly higher titers than in the absence of its host (Fig. 5). Phage titers in soil without CHA0-Rif decreased slowly (Fig. 5), indicating the absence of a phage- sensitive bacterial background population. No interfering background phage or rifampicin-resistant bacterial populations was detected in noninoculated soil. These results demonstrate the potential of a phage to drastically decimate the population size of an introduced pseudomonad in natural soil.

\section{Phage $\Phi$ GP100 reduces biocontrol capacity of P. fluorescens CHA0-Rif.}

The influence of phage $\Phi$ GP100 on the biocontrol ability of strain CHA0-Rif against a root rot and damping-off disease of cucumber caused by Pythium ultimum was tested in natural soil microcosms. Strain CHA0-Rif significantly improved, by approximately $15 \%$, shoot and root fresh weights of plants grown in the absence of the pathogen (Table 2). This was probably due to a suppressive effect of the strain on minor pathogens present in the natural soil that did not produce any obvious disease symptoms. It is also possible that the phytohormone indole-3-acetic acid excreted by strain CHA0-Rif (Beyeler et al. 1999) may have contributed to some extent to plant growth stimulation. Addition of $\Phi$ GP100 at a m.o.i of 1.6 abolished the plant growth-promoting effect of strain CHA0-Rif (Table 2). By contrast, the phage did not affect the positive effect on plant growth exerted by CHA0-Rif- $\Phi R$, a phage-resistant variant of strain CHA0-Rif (Table 2).

Pythium ultimum severely reduced growth and survival of cucumber plants when no bacteria were applied to soil (Table 2). Addition of strain CHA0-Rif to pathogen-infested soil enhanced plant survival by $25 \%$ and plant fresh weights by approximately $40 \%$ (Table 2 ). The biocontrol capacity of strain CHA0-Rif was completely abolished when $\Phi$ GP100 was present in soil, whereas the phage had no deleterious effect on

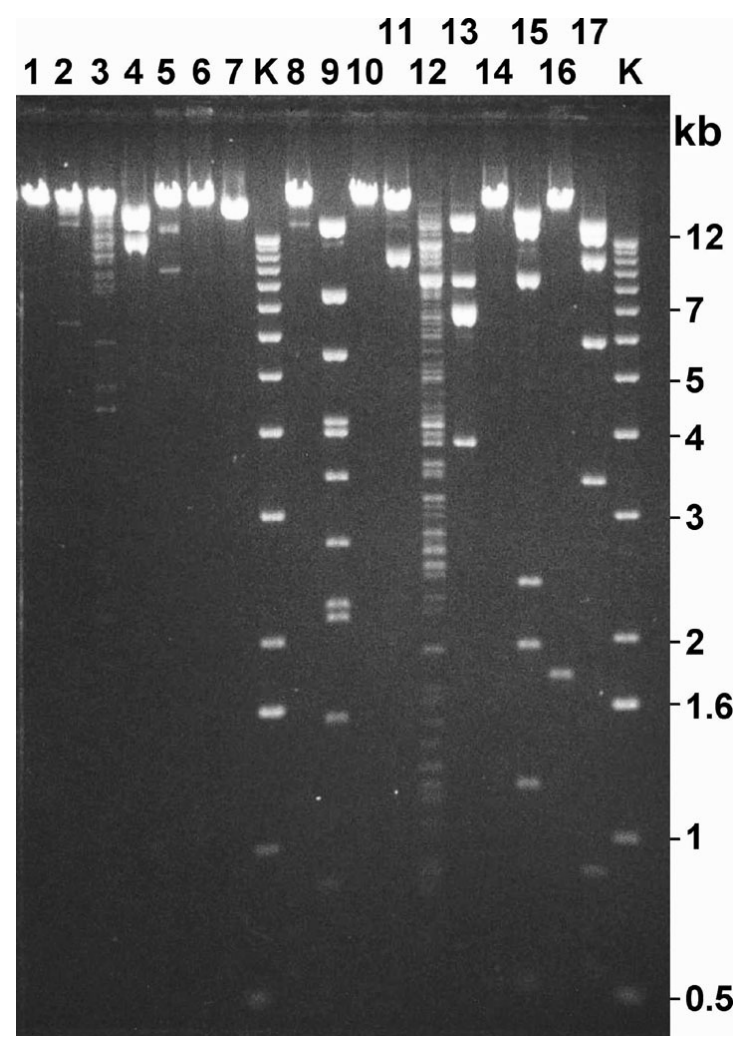

Fig. 2. DNA of $\Phi G P 100$ digested with restriction endonucleases to determine the bacteriophage genome size. Lane 1, undigested; lane 2, XbaI; lane 3, SphI; lane 4, SmaI; lane 5, SalI; lane 6, SacI; lane 7, PstI; lane 8, NotI; lane 9, NcoI; lane 10, MluI; lane 11, KpnI; lane 12, HindIII (partial digestion); lane 13, EcoRV; lane 14, EcoRI; lane 15, ClaI; lane 16, BamHI; and lane 17, ApaI. Lane K, 1-kb DNA ladder. 
disease suppression brought about by the phage-resistant bacterium CHA0-Rif- $\Phi \mathrm{R}$ (Table 2). As a control, all treatments without phage application also were supplemented with an autoclaved phage suspension and no significant differences could be detected (data not shown).

The negative effect of $\Phi$ GP100 on biocontrol capacity of strain CHA0-Rif was accompanied by a 100 -fold reduction of the population density of the bacterium on cucumber roots in the presence of the phage (Table 2). In contrast, ФGP100 had no negative effect on root colonization capacity of the phageresistant variant $\mathrm{CHA0-Rif- \Phi R}$ (Table 2). Interestingly, a majority of the CHA0-Rif cells reisolated from microcosms to which $\Phi$ GP100 had been added were resistant to the phage (Table 2), whereas cells grown in the absence of $\Phi$ GP100 remained phage sensitive. Phage titers were significantly higher in the presence of CHA0-Rif than in the presence of the phage-resistant bacterium or than in the absence of the bacterial host (Table 2), indicating that $\Phi$ GP100 was able to replicate in the soil microcosms only when the susceptible host was present. Taken together, these experiments demonstrate that bacteriophages can be an important factor affecting root colonization and biocontrol capacity of beneficial bacteria introduced into soil.

\section{DISCUSSION}

Previous studies have suggested that virulent bacteriophages may have the potential to influence populations of plant-beneficial pseudomonads in soil and in the rhizosphere (Ashelford et al. 1999a; Campbell et al. 1995; Smit et al. 1996; Stephens et al. 1987). The present work has taken this further and highlights the capacity of the lytic bacteriophage $\Phi$ GP100 to decimate the population of a plant-beneficial pseudomonad (i.e., Pseudomonas fluorescens CHA0) introduced into a natural soil environment. To our knowledge, this is the first study to demonstrate that a phage interferes with the biological control of a root disease.

\section{Phage characteristics.}

Based on morphological and genotypic characteristics, phage $\Phi$ GP100 appears to be a typical member of the Podo-

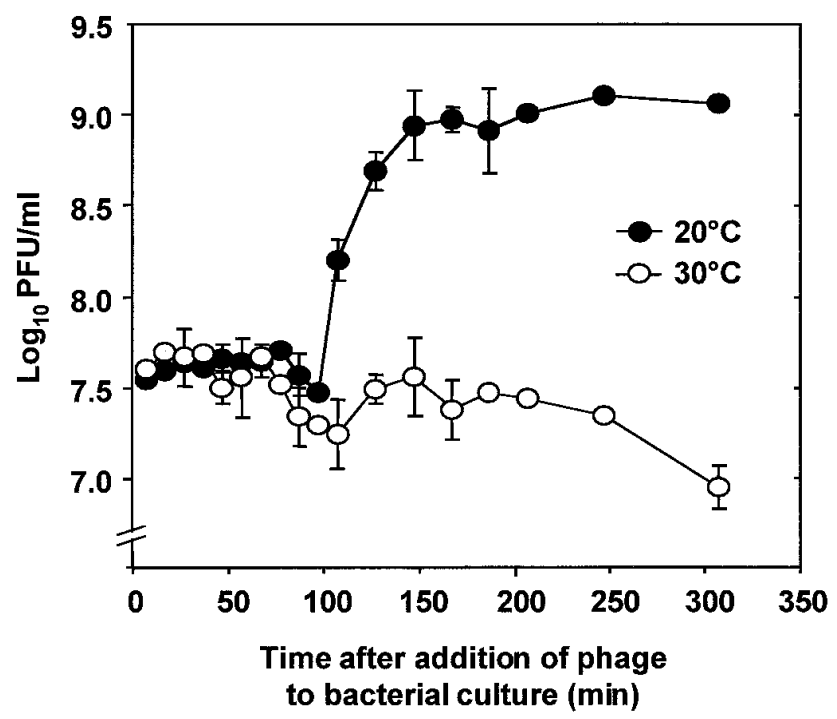

Fig. 3. Single-step growth curves for bacteriophage $\Phi$ GP100 propagated in Pseudomonas fluorescens $\mathrm{CHA} 0$ at $20^{\circ} \mathrm{C}(\bigcirc)$ and $30^{\circ} \mathrm{C}(\bigcirc)$. Means \pm standard error from two independent experiments are shown. Some of the error bars were too small to be included. viridae family (van Regenmortel et al. 2000). Members of this family represent some of the most commonly characterized phages of pseudomonads (Ackermann 2001; Bigby and Kropinski 1988; Park et al. 2000). An interesting feature of ФGP100 was its apparent temperature-dependent virulence. The phage was not able to replicate at temperatures above $25^{\circ} \mathrm{C}$ (Fig. 3) but showed optimal plaque formation at $20^{\circ} \mathrm{C}$ (i.e., at a temperature that is closer to that found in the natural habitat of its host). The nature of the temperature sensitivity of phage $\Phi$ GP100 is unknown. Remarkably, a similar loss of virulence at temperatures higher than $25^{\circ} \mathrm{C}$ has also been reported for another member of the Podoviridae family (Park et al. 2000) as well as for a member of the Myoviridae family (Ashelford et al. 1999b).

Phage GGP100 had a narrow host range. Besides strain CHA0, the phage was capable of infecting only some closely related Pseudomonas strains originating, however, from various soils worldwide (Table 1). These phage-sensitive strains cluster in the same ARDRA and RAPD groups and have the capacity to produce the potent antifungal polyketides $\mathrm{Phl}$ and Plt as a common phenotypic characteristic (Keel et al. 1996; Ramette et al. 2001; Wang et al. 2001). In contrast, Phl-producing pseudomonads clustering in a genotypically different group were resistant to the phage (Table 1). Therefore, phage ФGP100 seems to be highly specialized in infecting a particular type of pseudomonad (i.e., $\mathrm{Phl}^{+} \mathrm{Plt}^{+}$) strain. Strains of this type are known to belong to the best-performing biocontrol pseudomonads (Keel et al. 1996; Keel and Défago 1997; Wang et al. 2001); therefore, typing with ФGP100 might serve as a useful criterion in screening for $\mathrm{Phl}^{+} \mathrm{Plt}^{+}$biocontrol strains occurring worldwide. It would be interesting to see whether these bacteria share a common phage-specific receptor. Exopolysaccharide production (Schnider-Keel et al. 2001) and traits depending on the GacS-GacA two-component system (Haas et al. 2000) are not involved in sensitivity to the phage (Table 1). Previous studies illustrate that there is considerable diversity in the host range of different members of the Podoviridae family; these phages may infect only a specific bacterial strain (Bigby and Kropinski 1988), multiple strains of a bacterial species (Park et al. 2000; Scholl et al. 2001), or multiple species of a bacterial genus (Kelln and Warren 1971).

Several observations lead us to conclude that ФGP100 is a lytic phage. First, all attempts failed to induce the release of phage particles from spontaneous phage-resistant variants of strain CHA0 and its spontaneous rifampicin-resistant derivative CHA0-Rif. Second, hybridization experiments showed that the phage-resistant variants did not harbor phage DNA. Lysogeny has been suggested to be an advantage for phagehost interactions in soil (Marsh and Wellington 1994; Williams et al. 1987) and is frequently encountered in $P$. aeruginosa (Holloway and Krishnapillai 1975). However, temperate phages of other Pseudomonas spp., in particular of the $P$. fluorescens-putida group, appear to be rare (Campbell et al. 1995; Holloway and Krishnapillai 1975; Shaburova et al. 2000, 2001).

\section{Phage-host interactions in natural soil microcosms.}

The lytic bacteriophage ФGP100 used in the present work had a dramatic impact on the population size of the biocontrol bacterium $P$. fluorescens CHA0-Rif in soil and in the cucumber rhizosphere. In the presence of the phage at an m.o.i. of 1.6, CFU numbers of strain CHA0-Rif were reduced more than 100-fold from an initial density of approximately $10^{7}$ CFU per $g$ of soil and the decline of the sensitive host population was accompanied by a concomitant increase of phage titers (Fig. 5, Table 2). In a previous study, Stephens and as- 
sociates (1987) found a similar reduction of the population size of a fluorescent Pseudomonas strain caused by a lytic bacteriophage on sugar beet roots. However, these experiments were carried out in sterile soil. These authors found that an initial inoculum of at least $10^{6} \mathrm{CFU}$ per seed was necessary to allow for phage replication (O'Sullivan et al. 1990), in agreement with the suggestion that phages have an impact on bacterial survival and activity above a threshold of $10^{4}$ CFU per ml (Wiggins and Alexander 1985). Smit and associates (1996) reported a slight decrease in the population size of a $P$. fluorescens strain grown in natural bulk soil in the presence of a lytic phage. They could observe a significant negative effect of the phage only when nutrients were added to soil, however.

Here, we demonstrate that phage-induced reduction of root colonization completely abolished the biocontrol efficacy of $P$. fluorescens CHA0-Rif (Table 2). This finding has two important implications. First, it establishes lytic bacteriophages as relevant, largely neglected biotic factors which may contribute to the variable performance of biocontrol pseudomonads in natural soil environments. Second, it underscores the notion that biocontrol pseudomonads need to be present on roots at a certain population density to provide efficient biocontrol (Lugtenberg et al. 2001).

Phage ФGP100 did not affect root colonization capacity and disease suppressive effect of a spontaneous ФGP100-resistant variant of strain CHA0-Rif (Table 2). The biological basis of this phage resistance is not known. Interestingly, spontaneous phage-resistant variants were not only detected in vitro but also in the rhizosphere when the sensitive host CHA0-Rif was grown in the presence of $\Phi$ GP100 (Table 2). The rapid emergence of a phage-resistant subpopulation of

Table 1. Host range of bacteriophage $\Phi$ GP100

\begin{tabular}{|c|c|c|}
\hline Bacterial host & Reference or source & $\begin{array}{l}\text { Sensitivity to } \\
\text { phage } \Phi G P 100^{\mathrm{a}}\end{array}$ \\
\hline \multicolumn{3}{|l|}{ Pseudomonas fluorescens $\mathrm{CHA} 0$ and mutants: } \\
\hline CHA0 (wild type) & Voisard et al. 1994 & + \\
\hline CHA0-Rif (spontaneous Rif ${ }^{\mathrm{T}}$ variant of CHA0) & Natsch et al. 1994 & + \\
\hline CHA89 (gacA:: $\Omega-\mathrm{Km})$ & Laville et al. 1992 & + \\
\hline CHA510 (gacS::Tn5) & Bull et al. 2001 & + \\
\hline CHA211 (тисA::Tn5) & Schnider-Keel et al. 2001 & + \\
\hline CHA213M $(\Delta т и с A)$ & Schnider-Keel et al. 2001 & + \\
\hline CHA212 $(\Delta \operatorname{alg} U)$ & Schnider-Keel et al. 2001 & + \\
\hline \multicolumn{3}{|l|}{ Phl-producing fluorescent Pseudomonas spp. ${ }^{\text {. }}$ : } \\
\hline $\begin{array}{l}\mathrm{Phl}^{+}{ }^{+} \mathrm{Plt}^{+} \text {strains Pf1, PINR2, PINR3, PGNR1, PGNR2, PGNR3, PGNR4, } \\
\text { PGNL1, K93.25, K94.4, K94.5, K94.6, and K94.30 clustering, like }\end{array}$ & $\begin{array}{l}\text { Keel et al. 1996; Ramette et al. 2001; } \\
\text { Wang et al. } 2001\end{array}$ & \\
\hline CHA0, in ARDRA group 1 and RAPD group 1 & & + \\
\hline $82 \mathrm{Phl}^{+} \mathrm{Plt}^{-}$strains clustering in ARDRA group 2 & Keel et al. 1996; Ramette et al. 2001; Wang et al. 2001 & - \\
\hline $\begin{array}{l}\mathrm{Phl}^{+} \mathrm{Plt}^{+} \text {strains Pf- } 5 \text { and PF clustering in ARDRA group } 1 \text { and } \\
\text { RAPD group } 2\end{array}$ & $\begin{array}{l}\text { Howell \& Stipanovic 1979; Keel et al. 1996; } \\
\text { Levy et al. 1992; Wang et al. } 2001\end{array}$ & \pm \\
\hline \multicolumn{3}{|l|}{ Pseudomonas spp.: } \\
\hline P. aeruginosa $\mathrm{PAO} 1$ & ATCC 15692 & - \\
\hline P. chlororaphis & ATCC 9446 & - \\
\hline P. fluorescens biotype A & ATCC 13525 & - \\
\hline P. fluorescens, 17 different strains & $\begin{array}{l}\text { Laboratory collection; J. Sørensen; L. S. Thomashow } \\
\text { and D. M. Weller; F. O'Gara }\end{array}$ & - \\
\hline P. mendocina & NCIB 10541 & - \\
\hline P. putida & ATCC 12633 & - \\
\hline P. stutzeri & ATCC 11607 & - \\
\hline P. syringae subsp. syringae & ATCC 19310 & - \\
\hline \multicolumn{3}{|l|}{ Other gram-negative bacteria: } \\
\hline Acinetobacter calcoaceticus & DSM 588 & - \\
\hline Bradyrhizobium japonicum & Laboratory collection & - \\
\hline Burkholderia cepacia & ATCC 17616 & - \\
\hline Burkholderia gladioli & Laboratory collection & - \\
\hline Chromobacterium violaceum & ATCC 31532 & - \\
\hline Comamonas testosteroni & ATCC 11996 & - \\
\hline Delftia acidovorans & ATCC 17438 & - \\
\hline Erwinia carotovora subsp. atroseptica & R. Grimm & - \\
\hline Erwinia carotovora subsp. carotovora & R. Grimm & - \\
\hline Escherichia coli $\mathrm{K} 12$ & & - \\
\hline Klebsiella pneumoniae subsp. pneumoniae & ATCC 25306 & - \\
\hline Mesorhizobium loti & ATCC 35173 & - \\
\hline Rhizobium leguminosarum & Laboratory collection & - \\
\hline Rhizobium radiobacter & Laboratory collection & - \\
\hline Rhizobium rhizogenes & Laboratory collection & - \\
\hline Salmonella enterica serovar typhimurium & T. Köhler & - \\
\hline Serratia marcescens & J.-A. Hutsul & - \\
\hline Serratia rubidaea & J.-A. Hutsul & - \\
\hline Vibrio natriegens & NCIB 857 & - \\
\hline Xanthomonas campestris pv. campestris & R. Grimm & - \\
\hline
\end{tabular}

${ }^{a}$ Sensitivity to phage $\Phi$ GP100 was determined by the cross-streaking test and the spot lysis assay described in text; $+=$ confluent lysis in the bacterial lawn at the site of phage addition at $10 \mathrm{PFU}$ per $\mu \mathrm{l} ; \pm=$ lysis at $10^{4} \mathrm{PFU}$ per $\mu \mathrm{l} ;-=$ no lysis at $10^{6} \mathrm{PFU}$ per $\mu \mathrm{l}$.

${ }^{\mathrm{b}} \mathrm{Phl}=2$,4-diacetylphloroglucinol, Plt = pyoluteorin, ARDRA = amplified 16S ribosomal DNA restriction analysis, RAPD = randomly amplified polymorphic DNA. A worldwide collection of $97 \mathrm{Phl}$-producing pseudomonads belonging to two genotypically and phenotypically distinct groups (i.e., the $\mathrm{Phl}^{+} \mathrm{Plt}^{+}$ ARDRA group 1, including strain CHA0, and the $\mathrm{Phl}^{+} \mathrm{Plt}^{-}$ARDRA group 2, respectively) was scored for phage sensitivity. ARDRA group 1 comprises a subgroup of two strains (Pf-5 and PF) that cluster in a separate RAPD group. 
strain CHA0-Rif suggests that the bacterium has developed strategies to cope with the attack of certain phages. Nevertheless, our results indicate that, in the case of Pythium spp. (i.e., a pathogen which damages the roots at a very early stage), phage resistance may evolve too slowly to allow for recovery of the bacterial population from the phage attack and, hence, for biocontrol (Table 2). It has been shown previously that the presence of lytic bacteriophages can result in a significant decline of the numbers of phage-sensitive Rhizobium isolates on roots of clover, often accompanied by an increased proportion of a phage-resistant variant (Barnet 1980). In marine phage-host systems, the emergence of phage-resistant variants gradually can compensate for the losses caused by the initial viral lysis of the sensitive host, thus maintaining the overall density of the bacterial community at an even level (Middelboe 2000; Waterbury and Valois 1993).

In conclusion, our present work provides new insights into biotic factors that can influence survival, root colonization, and biocontrol capacity of plant-beneficial pseudomonads. The exploitation of phage-resistant variants may be a way to improve persistence and beneficial activity of bacterial inoculants for use in natural soil environments. Clearly a better understanding of the dynamics of phage-host interactions in soil is needed, especially in habitats like the rhizosphere, which are considered to be "hot spots" for bacterial activity.

\section{MATERIALS AND METHODS}

\section{Microorganisms and culture media.}

P. fluorescens strain CHA0 (Voisard et al. 1994), its spontaneously rifampicin-resistant derivative CHA0-Rif (Natsch et al. 1994), as well as bacterial strains used for host range studies (Table 1) were routinely cultivated on nutrient agar (NA) (Stanisich and Holloway 1972) and in Luria-Bertani broth (LB) (Sambrook et al. 1989) at $30^{\circ} \mathrm{C}$, unless otherwise specified. When appropriate, growth media for strain CHA0-Rif, which was used for experiments with natural soil microcosms, were supplemented with rifampicin at $100 \mu \mathrm{g}$ per ml. Pythium ultimum strain 67-1 was cultured on malt agar and, for use in
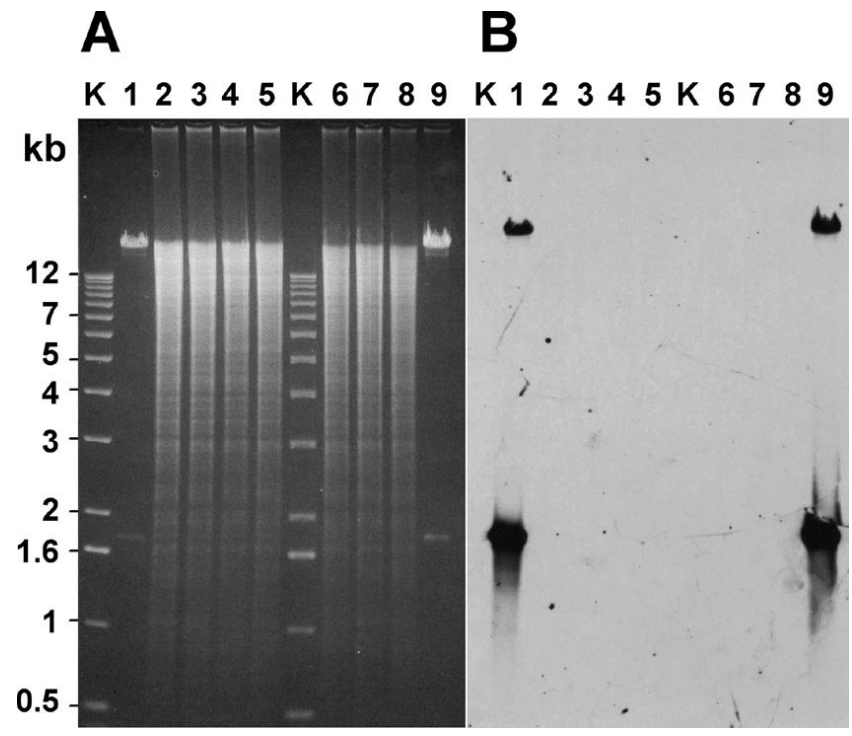

Fig. 4. A, BamHI restriction digests of DNA of: lanes 1 and 9, bacteriophage $\Phi$ GP100; lane 2, Pseudomonas fluorescens CHA0-Rif; and lanes 3 to 8, six $\Phi$ GP100-resistant variants of strain CHA0-Rif. B, Southern blot of the same gel probed with a digoxygenin-labeled 1.8-kb BamHI fragment of $\Phi$ GP100-DNA. Lane K, 1-kb DNA ladder. plant disease suppression assays, on autoclaved millet seeds as described previously (Maurhofer et al. 1992).

Phage isolation, growth, purification, and titration.

Bacteriophage ФGP100 was isolated from P. fluorescens strain CHA0-Rif that had been reisolated from cucumber roots grown in a natural Swiss soil. The phage was detected as contaminating plaques in lawns of strain CHA0-Rif grown on NA. Before preparing lysate stocks of $\Phi$ GP100, the phage was plaque-purified several times to ensure homogeneity (Sambrook et al. 1989). Phage lysate stocks were prepared by propagating the phage overnight at $20^{\circ} \mathrm{C}$ in strain $\mathrm{CHA} 0$ grown on NA or in LB, following the procedures described by Day and Marchesi (1996) or by Sambrook and associates (1989), respectively. The resulting lysates were centrifuged at $10,000 \times g$, filtered (Millipore filter; pore size $0.22 \mu \mathrm{m}$ ), and tested for bacterial contamination. This procedure usually yielded approximately $10^{8}$ to $10^{9} \mathrm{PFU}$ per ml of lysate. When appropriate, phage lysates were further concentrated and purified as described by Sambrook and associates (1989) for bacteriophage $\lambda$, involving treatment with DNase I, RNase, and 1 $\mathrm{M} \mathrm{NaCl}$, precipitation with $10 \%$ (wt/vol) polyethylene glycol (PEG 8000), and several centrifugation steps. By this treatment, phage titers could be increased to approximately $10^{10}$ to $10^{11} \mathrm{PFU}$ per ml. Phage lysates were kept at $4^{\circ} \mathrm{C}$. Long-term storage was in $50 \%$ ( vol/vol) glycerol at $-80^{\circ} \mathrm{C}$.

Phage titers were determined by the double agar layer technique (Adams 1959). For the top agar layer, a mixture of 3.5 $\mathrm{ml}$ of soft NA with $0.5 \%$ agar) with $300 \mu$ of an LB overnight culture of the host bacterium and $100 \mu \mathrm{l}$ of 10 -fold serial dilutions of the phage lysates was prepared. The mixture then was poured onto the bottom agar layer consisting of NA. Plates were incubated at $20^{\circ} \mathrm{C}$ for 24 to $36 \mathrm{~h}$ and then scored for the occurrence of plaques in the bacterial growth.

\section{DNA manipulations.}

Chromosomal DNA from $P$. fluorescens was isolated as described by Gamper and associates (1992). DNA from purified

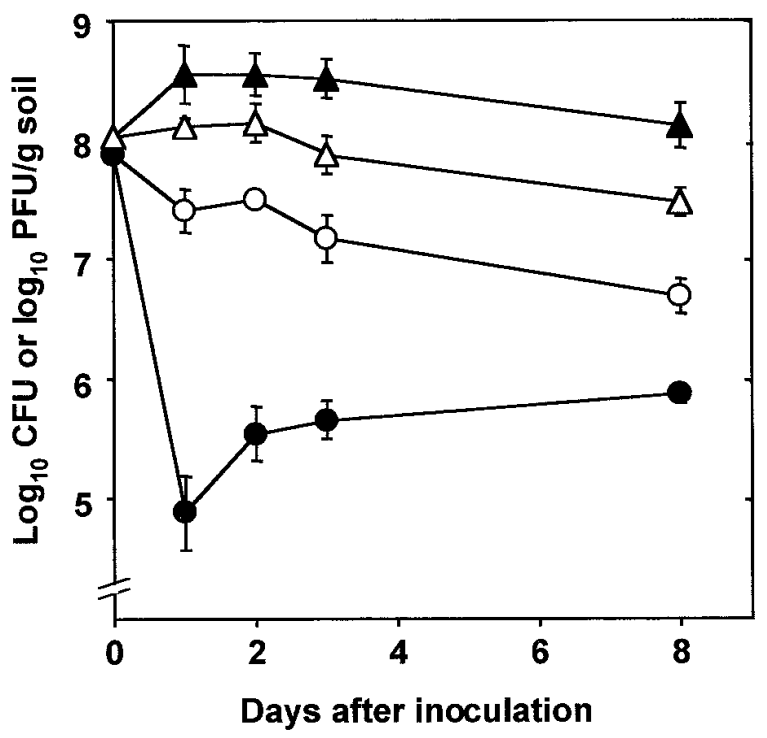

Fig. 5. Interaction between Pseudomonas fluorescens CHA0-Rif and bacteriophage $\Phi$ GP100 in natural soil microcosms. $\bigcirc=$ CFU of CHA0Rif in the absence of the phage, $=\mathrm{CFU}$ of CHA0-Rif in the presence of the phage, $\Delta=$ PFU of $\Phi$ GP100 in the absence of the host, $\boldsymbol{\Delta}=$ PFU of $\Phi$ GP100 in the presence of the host. The phage and its host were added to soil at a multiplicity of infection of 1.6. Microcosms were incubated at $20^{\circ} \mathrm{C}$. Means \pm standard error from three independent experiments are shown. 
phage ФGP100 particles was isolated according to the protocol of Day and Marchesi (1996). Restriction enzyme digestions and agarose gel electrophoresis were performed using standard procedures (Sambrook et al. 1989). For an estimation of the approximate genome size, phage DNA was digested with ApaI, BamHI, ClaI, EcoRI, EcoRV, HindIII, KpnI, MluI, NcoI, NotI, PstI, SacI, SalI, SmaI, SphI, XbaI, and XhoI and with combinations of enzymes. Restriction fragments were purified from lowmelting-point agarose gels using the Geneclean II kit (Bio 101, La Jolla, CA, U.S.A.). Southern transfer of phage and bacterial DNA to Hybond $\mathrm{N}$ membranes (Amersham Biosciences, Dübendorf, Switzerland), random-primed labeling of a 1.8-kb BamHI fragment of phage DNA with digoxigenin-11-dUTP, hybridization, and detection (Roche Diagnostics, Rotkreuz, Switzerland) were done as recommended by the suppliers.

\section{Transmission electron microscopy of phage.}

Aliquots of $5 \mu \mathrm{l}$ of freshly prepared, purified, and concentrated phage lysate $\left(10^{10}\right.$ PFU per ml $)$ were spotted onto carbon-film-coated transmission electron microscopy grids. Grids then were stained with $2 \%$ (wt/vol) phosphotungstic acid $(\mathrm{pH}$ 7.4) for $1 \mathrm{~min}$ and allowed to air dry. Grids were examined with a Philips CM12 transmission electron microscope (Heindoven, The Netherlands). Electron micrographs were taken at a magnification of $\times 66,000$. Phage dimensions were determined using tobacco mosaic virus as a standard. A total of 20 particles was measured.

\section{Heat, UV, and chloroform sensitivity of phage.}

Temperature sensitivity of the phage was assayed by incubating $1-\mathrm{ml}$ aliquots of phage lysate $\left(10^{8} \mathrm{PFU}\right.$ per $\left.\mathrm{ml}\right)$ in Eppendorf tubes at $20,30,37,60$, and $80^{\circ} \mathrm{C}$ for up to $24 \mathrm{~h}$. For testing sensitivity to UV irradiation, $0.5-\mathrm{ml}$ aliquots of the phage lysate were placed in microtiter dishes and exposed for $5,10,30$, and $60 \mathrm{sec}$ to irradiation from a UV lamp (254 nm, $2 \times 8 \mathrm{~W}$, Camag, Muttenz, Switzerland) placed at a distance of $15 \mathrm{~cm}$ to the lysate. Sensitivity to chloroform was tested by mixing $0.5-\mathrm{ml}$ aliquots of the lysate with $0.1,1$, and $10 \%$ (vol/vol) chloroform and incubating the mixture at $4^{\circ} \mathrm{C}$ for 1,5 , and 10 days. In all experiments, phage survival was assessed by the agar overlay technique described above.
Single-step growth curve experiments.

A modification of the protocol of Ellis and Delbrück (1939) was used. Equal volumes $(1 \mathrm{ml})$ of phage lysate $\left(3 \times 10^{8} \mathrm{PFU}\right.$ per $\mathrm{ml}$ ) and an exponential-growth-phase culture of $P$. fluorescens strains CHA0 or CHA0-Rif $\left(1.4 \times 10^{8} \mathrm{CFU}\right.$ per ml $)$ were mixed together and incubated at $20^{\circ} \mathrm{C}$ for $7 \mathrm{~min}$ to allow for phage adsorption. Immediately thereafter, the mixture was diluted $10^{-4}$ in $30 \mathrm{ml}$ of fresh LB in 100-ml Erlenmeyer flasks. Cultures were incubated at 20 or $30^{\circ} \mathrm{C}$ with rotational shaking (200 rpm), and $100-\mu \mathrm{l}$ samples were taken at 10 - or 20 -min intervals. Phage titers were monitored by the agar overlay technique described above. Burst size was calculated as the final yield of phage divided by the initial number of PFU and by taking into account the number of unadsorbed phages, determined after chloroform treatment of the infected bacterial cells at $10 \mathrm{~min}$ (Adams 1959).

\section{Host range studies of phage.}

To determine the host range of $\Phi$ GP100, a collection of gram negative bacterial strains (Table 1) was tested for phage sensitivity by using the cross-streaking test (Day and Marchesi 1996). Therefore, $30 \mu \mathrm{l}$ of phage lysate $\left(10^{9} \mathrm{PFU}\right.$ per $\mathrm{ml}$ ) was streaked on a NA plate and allowed to dry before a loopful of an LB overnight culture of the test bacteria was cross-streaked against the lysate. On each plate, the phagesensitive hosts CHA0 or CHA0-Rif were included as controls. In addition, phage sensitivity of the bacteria also was evaluated by a spot lysis assay (Day and Marchesi 1996) in which $10 \mu \mathrm{l}$ of 10 -fold serially diluted phage lysate $\left(10^{9} \mathrm{PFU}\right.$ per $\mathrm{ml}$ ) was spotted on soft NA overlays containing $300 \mu \mathrm{l}$ of a LB overnight culture of the test bacterium. For both experiments, the plates were incubated at $20^{\circ} \mathrm{C}$ for 24 to $36 \mathrm{~h}$ and then scored for the occurrence of partial or confluent lysis in the bacterial growth.

\section{Selection of phage-resistant variants of P. fluorescens CHA0 and CHA0-Rif.}

When plating phage $\Phi$ GP100 together with its host strains CHA0 or CHA0-Rif, distinct microcolonies were observed that formed within 2- to 3-day-old clear plaques on the bacterial lawn. To test whether these phage-tolerant microcolonies were due to the formation of a lysogenic association with the

Table 2. Influence of bacteriophage $\Phi G P 100$ on the suppression of Pythium damping-off and root rot of cucumber by Pseudomonas fluorescens CHA0-Rif and its phage-resistant variant CHA0-Rif- $\Phi$ R in natural soil

\begin{tabular}{|c|c|c|c|c|c|c|}
\hline $\begin{array}{l}\text { Bacterial strain and } \\
\text { bacteriophage added }^{a}\end{array}$ & $\begin{array}{l}\text { Pythium } \\
{\text { sp. } \text { added }^{\mathrm{a}}}^{\text {Pat }}\end{array}$ & $\begin{array}{l}\text { Surviving plants } \\
\text { per flask }(\%)^{\mathbf{b}}\end{array}$ & $\begin{array}{l}\text { Shoot fresh weight } \\
\text { per flask }(\mathrm{g})^{\mathrm{b}}\end{array}$ & $\begin{array}{l}\text { Root fresh weight } \\
\text { per flask }(\mathrm{g})^{\mathbf{b}}\end{array}$ & $\begin{array}{c}\text { Pseudomonas } \\
\text { fluorescens }\left(\log _{10} \text { CFU }\right. \\
\text { per g of roots })^{\mathrm{b}, \mathrm{c}}\end{array}$ & $\begin{array}{c}\text { Phage } \Phi \text { GP100 } \\
\text { (log }_{10} \text { PFU per g } \\
\text { of roots) })^{b}\end{array}$ \\
\hline None & - & $92 \mathrm{a}$ & $1.21 \mathrm{~b}$ & $0.39 \mathrm{~b}$ & ND & ND \\
\hline ФGP100 & - & 98 a & $1.21 \mathrm{~b}$ & $0.38 \mathrm{~b}$ & ND & $6.53 \mathrm{~b}$ \\
\hline CHA0-Rif & - & $99 \mathrm{a}$ & $1.41 \mathrm{a}$ & $0.45 \mathrm{a}$ & $7.31 \mathrm{~b}$ & ND \\
\hline CHA0-Rif + ФGP100 & - & $94 \mathrm{a}$ & $1.16 \mathrm{~b}$ & $0.34 \mathrm{~b}$ & $5.07 \mathrm{~d}$ & $7.28 \mathrm{a}$ \\
\hline CHA0-Rif- $\Phi \mathrm{R}$ & - & $100 \mathrm{a}$ & $1.49 \mathrm{a}$ & $0.50 \mathrm{a}$ & $7.35 \mathrm{~b}$ & ND \\
\hline CHA0-Rif- $\Phi \mathrm{R}+\Phi G P 100$ & - & $100 \mathrm{a}$ & $1.44 \mathrm{a}$ & $0.49 \mathrm{a}$ & $8.12 \mathrm{a}$ & $6.86 \mathrm{~b}$ \\
\hline None & + & $54 \mathrm{~cd}$ & $0.52 \mathrm{de}$ & $0.15 \mathrm{~d}$ & ND & ND \\
\hline ФGP100 & + & $59 \mathrm{c}$ & $0.58 \mathrm{~d}$ & $0.16 \mathrm{~d}$ & ND & $6.59 \mathrm{~b}$ \\
\hline CHA0-Rif & + & $79 \mathrm{~b}$ & $0.84 \mathrm{c}$ & $0.24 \mathrm{c}$ & $7.77 \mathrm{ab}$ & ND \\
\hline CHA0-Rif + ФGP100 & + & $39 \mathrm{~d}$ & $0.40 \mathrm{e}$ & $0.13 \mathrm{~d}$ & $6.13 \mathrm{c}$ & $7.72 \mathrm{a}$ \\
\hline CHA0-Rif- $\Phi R$ & + & $74 \mathrm{~b}$ & $0.79 \mathrm{c}$ & $0.22 \mathrm{c}$ & $7.57 \mathrm{~b}$ & ND \\
\hline CHA0-Rif- $\Phi \mathrm{R}+\Phi G P 100$ & + & $72 \mathrm{~b}$ & $0.76 \mathrm{c}$ & $0.21 \mathrm{c}$ & $8.10 \mathrm{a}$ & $7.03 \mathrm{ab}$ \\
\hline
\end{tabular}

${ }^{a}$ P. fluorescens strains and $\Phi$ GP100 were added at, respectively, $0.8 \times 10^{7} \mathrm{CFU}$ and $1.3 \times 10^{7} \mathrm{PFU}$ per $\mathrm{g}$ of soil contained within $200-\mathrm{ml}$ flasks $(60 \mathrm{~g}$ of soil per flask), before planting three 72-hour-old, sterile-grown cucumber seedlings per flask. Pythium ultimum was added as a millet-seed inoculum at $0.25 \mathrm{~g}$ per kg of soil 2 days prior to planting. Plants were harvested after 7 days.

b Data represent the means from five individual repetitions of the same experimental setup, with 6 to 12 replicates (flasks containing three cucumber plants) per treatment in each experiment. Means within the same column followed by different letters differ significantly at $P=0.05$, according to Fisher's leastsignificant-difference test. $\mathrm{ND}=$ not detected.

${ }^{\mathrm{c}}$ When grown in the presence of ФGP100, $89 \pm 13$ and 100\% (78 \pm 15 and 100\% in treatments with Pythium sp.) of the number of CFU of strains CHA0Rif and CHA0-Rif- $\Phi$ R, respectively, reisolated from roots at the end of the experiment were resistant to the phage. 
host, they were picked from the plaques and purified by successive subculturing to remove attached phage particles (Day and Marchesi 1996). Phage resistance of candidate strains was confirmed by the cross-streaking test and the spot lysis assay described above. Phage-resistant variants (20 for each host strain) were compared with their parental strains $\mathrm{CHA} 0$ or CHA0-Rif for growth rate, production of secondary metabolites, extracellular enzymes, and siderophores and for their in vitro inhibitory activity as described elsewhere (Keel et al. 1992, 1996; Sacherer et al. 1994). Phage-resistant variants were then further analyzed for spontaneous and UV-inducible release of phage particles. Therefore, aliquots of 10 $\mu \mathrm{l}$ of phage-resistant overnight cultures were spotted on NA and exposed to UV light for $0,10,30$, or $60 \mathrm{sec}$. After incubation at $20^{\circ} \mathrm{C}$ for $16 \mathrm{~h}$, colonies were cut out and suspended in $500 \mu \mathrm{l}$ of LB. Suspensions were incubated at $20^{\circ} \mathrm{C}$ for $2 \mathrm{~h}$ and then assayed for potential phage release by spotting $30 \mu \mathrm{l}$ on a lawn of the phage-sensitive parental strains CHA0 or CHA0-Rif. After overnight incubation at $20^{\circ} \mathrm{C}$, lawns of the indicator strains were checked for zones of cell lysis. In addition, the phage-resistant variants were tested for the presence of lysogens by Southern hybridization of bacterial DNA with a 1.8-kb digoxygenin-labeled BamHI fragment of phage DNA.

\section{Phage-host interactions in natural soil microcosms.}

Interactions between phage $\Phi \mathrm{GP} 100$ and P. fluorescens were monitored in natural soil, using the rifampicin-resistant variant CHA0-Rif as the host. Natural sandy loam soil from Eschikon, Switzerland (Natsch et al. 1994), was collected from the upper $30 \mathrm{~cm}$ of the soil profile and passed through a $5-\mathrm{mm}$ mesh screen prior to use. The water content of the soil was approximately $20 \%$ (wt/wt), corresponding to a water potential of approximately $-0.03 \mathrm{MPa}$. For micocosms, aliquots of $10 \mathrm{~g}$ of soil were placed into $50-\mathrm{ml}$ sterile plastic tubes (Labcon, San Rafael, CA, U.S.A.). Bacterial cell suspensions were prepared from exponential-growth-phase cultures grown in $\mathrm{LB}$ at $24^{\circ} \mathrm{C}$. Cells were washed twice in sterile distilled water and cell density was adjusted to an optical density at $600 \mathrm{~nm}$ of 1.0 . The resulting suspension $(0.75 \mathrm{ml}$ per tube) was mixed into soil with a sterile syringe to give $7.6 \times 10^{7} \mathrm{CFU}$ per $\mathrm{g}$ of soil. Thereafter, $0.75 \mathrm{ml}$ of a suspension of phage $\Phi$ GP100 $\left(1.2 \times 10^{8}\right.$ PFU per $g$ of soil $)$ was added to the soil. Tubes were sealed with a screw cap to maintain constant soil humidity during the experiment and were incubated at $20^{\circ} \mathrm{C}$ in the dark. For isolation of strain CHA0-Rif and phage $\Phi$ GP100 from soil, $10 \mathrm{ml}$ of sterile distilled water was added to the tubes. The tubes were vigorously shaken at $240 \mathrm{rpm}$ for $30 \mathrm{~min}$ and the resulting soil suspension was 10 -fold serially diluted in sterile distilled water. Cultivable cells of strain CHA0-Rif were recovered on NA containing rifampicin at $100 \mu \mathrm{g}$ per ml. Phage titers were determined by the same double agar layer technique described above, except that rifampicin at $100 \mu \mathrm{g}$ per ml was added to the bottom and top agar layers.

\section{Plant disease suppression assays.}

The effect of phage $\Phi G P 100$ on the disease suppressive capacity of $P$. fluorescens $\mathrm{CHA} 0$-Rif and its phage-resistant variant CHA0-Rif- $\phi \mathrm{R}$ (discussed above) was tested in soil microcosms. Aliquots of $60 \mathrm{~g}$ of natural Eschikon soil (Natsch et al. 1994) were distributed into 200-ml Erlenmeyer flasks with wide openings. When appropriate, the soil was artificially infested with Pythium ultimum by adding $2.5 \mathrm{~g}$ of a 5-day-old millet-seed inoculum (Maurhofer et al. 1992) of the pathogen per $\mathrm{kg}$ of soil. After incubation at $24^{\circ} \mathrm{C}$ for 48 $h$, the pathogen-infested soil was thoroughly mixed with noninfested soil at a ratio of 1:10 (wt/wt) prior to addition to the flasks. Bacteria and phage suspensions were added to soil as described above, respectively, at $0.8 \times 10^{7} \mathrm{CFU}$ per $\mathrm{g}$ of soil and $1.3 \times 10^{7}$ PFU per $g$ of soil in a final volume of $5 \mathrm{ml}$ per flask. Control flasks received the same amount of sterile water or autoclaved phage suspension. Three sterile-grown, 72-hour-old cucumber seedlings (Cucumis sativus cv. Chinese Snake) were then placed in each flask as previously described (Maurhofer et al. 1992). Seedlings were covered with $10 \mathrm{~g}$ of nontreated soil and flasks were sealed with cotton stoppers. The microcosms were incubated in a randomized block design in a growth chamber at $80 \%$ relative humidity and $22^{\circ} \mathrm{C}$ with light $\left(200 \mu \mathrm{mol} \mathrm{sec} \mathrm{sm}^{-1}\right.$; ratio of 1.37 of light at $660 \mathrm{~nm}$ to $730 \mathrm{~nm}$ ) for $16 \mathrm{~h}$, followed by an 8-h dark period at $15^{\circ} \mathrm{C}$. No watering was necessary. At 7 days after inoculation, the percentage of surviving plants was determined. Plants were removed from the flasks, washed, briefly dried with paper towels, and weighed. Roots from each flask were pooled and transferred into $50-\mathrm{ml}$ plastic tubes containing $20 \mathrm{ml}$ of sterile distilled water. Tubes were vigorously shaken at $240 \mathrm{rpm}$ for $30 \mathrm{~min}$ and the resulting suspensions were used to determine CFU and PFU numbers as described above. For an estimate of the percentage of newly emerged, phage-resistant cultivable CHA0-Rif cells present on roots at the end of the experiment, a random selection of 100 colonies per treatment was tested for phage sensitivity by using the cross-streaking test described above. Data represent the means from five independent repetitions of the same experiment, with 6 to 12 replicates per treatment in each experiment (one replicate corresponds to one flask containing three plants). Data were analyzed for significance with variance analysis, followed by Fisher's least-significant-difference test. Data for CFU and PFU counts were $\log _{10}$-transformed prior to statistical analysis.

\section{ACKNOWLEDGMENTS}

We thank V. Krishnapillai (Monash University, Melbourne), U. Schnider-Keel, F. Roch, and S. Heeb for helpful advice; G. Défago and M. Zala (ETH Zürich), R. Grimm (FAW Wädenswil), J.-A. Hutsul (University of Mannitoba), T. Köhler (Université de Genève), F. O'Gara (University College Cork), J. Sørensen (KVL, Copenhagen), L. S. Thomashow, and D. M. Weller (Washington State University, Pullman) for providing bacterial strains; and a joint research foundation of the University of Lausanne and the Swiss Federal Institute of Technology, Lausanne (Fonds de recherche UNIL-EPFL 1998), and European project IMPACT2 (BIO4CT 960027) for financial support.

\section{LITERATURE CITED}

Ackermann, H.-W. 2001. Frequency of morphological phage descriptions in the year 2000. Arch. Virol. 146:843-857.

Ackermann, H.-W., Audurier, A., Berthiaume, L., Jones, L. A., Mayo, J. A., and Vidaver, A. K. 1978. Guidelines for bacteriophage characterisation. Adv. Virus Res. 23:1-24.

Adams, M. H. 1959. Bacteriophages. Interscience Publishers, Inc., New York.

Ashelford, K. E., Day, M. J., Bailey, M. J., Lilley, A. K., and Fry, J. C. 1999a. In situ population dynamics of bacterial viruses in a terrestrial environment. Appl. Environ. Microbiol. 65:169-174.

Ashelford, K. E., Fry, J. C., Bailey, M. J., Jeffries, A. R., and Day, M. J. 1999b. Characterization of six bacteriophages of Serratia liquefaciens CP6 isolated from the sugar beet phytosphere. Appl. Environ. Microbiol. 65:1959-1965.

Ashelford, K. E., Norris, S. J., Fry, J. C., Bailey, M. J., and Day, M. J. 2000. Seasonal population dynamics and interactions of competing bacteriophages and their host in the rhizosphere. Appl. Environ. Microbiol. 66:4193-4199.

Barnet, Y. M. 1980. The effect of rhizobiophages on populations of Rhizobium trifolii in the root zone of clover plants. Can. J. Microbiol. 26:572-576.

Beyeler, M., Keel, C., Michaux, P., and Haas, D. 1999. Enhanced produc- 
tion of indole-3-acetic acid by a genetically modified strain of Pseudomonas fluorescens $\mathrm{CHA} 0$ affects root growth of cucumber but does not improve protection of the plant against Pythium root rot. FEMS (Fed. Eur. Microbiol. Soc.) Microbiol. Ecol. 28:225-233.

Bigby, D., and Kropinski, A. M. 1989. Isolation and characterization of a Pseudomonas aeruginosa bacteriophage with a very limited host range. Can. J. Microbiol. 35:630-635.

Bull, C. T., Duffy, B., Voisard, C., Défago, G., Keel, C., and Haas, D. 2001. Characterization of spontaneous gacS and gacA regulatory mutants of Pseudomonas fluorescens biocontrol strain CHA0. Antonie Leeuwenhoek 79:327-336.

Campbell, J. I. A., Albrechtsen, M., and Sorensen, J. 1995. Large Pseudomonas phages isolated from barley rhizosphere. FEMS (Fed. Eur. Microbiol. Soc.) Microbiol. Ecol. 18:63-74.

Cresswell, N., Herron, P. R., Saunders, V. A, and Wellington, E. M. H. 1992. The fate of introduced streptomycetes plasmid and phage populations in a dynamic soil system. J. Gen. Microbiol. 138:659666.

Day, M. J., and Marchesi, J. R. 1996. Transduction in the aquatic environment. Pages 1-21 in: Molecular Microbial Ecology Manual, 5.3.1. A. D. L. Akkermans, J. D. van Elsas, and F. J. de Bruijn, eds. Kluwer Academic Publishers, Dordrecht, The Netherlands.

Ellis, E., and Delbrück, M. 1939. The growth of bacteriophage. J. Gen. Physiol. 22:365-384.

Elsherif, M., and Grossmann, F. 1996. Role of biotic factors in the control of soil-borne fungi by fluorescent pseudomonads. Microbiol. Res. 151:351-357.

Fuhrman, J. A. 1999. Marine viruses and their biogeochemical and ecological effects. Nature 399:541-548.

Gamper, M., Ganter, B., Polito, M. R., and Haas, D. 1992. RNA-processing modulates the expression of the $\operatorname{arcDABC}$ operon in Pseudomonas aeruginosa. J. Mol. Biol. 226:943-957.

Germida, J. J. 1986. Population dynamics of Azospirillum brasilense and its bacteriophage in soil. Plant Soil 90:117-128.

Haas, D., Blumer, C., and Keel, C. 2000. Biocontrol ability of fluorescent pseudomonads genetically dissected: Importance of positive feedback regulation. Curr. Opin. Biotechnol. 11:290-297.

Herron, P. R., and Wellington, E. M. H. 1994. Population dynamics of phage-host interactions and phage conversion of streptomycetes in soil. FEMS (Fed. Eur. Microbiol. Soc.) Microbiol. Ecol. 12:25-32.

Holloway, B. W., and Krishnapillai, V. 1975. Bacteriophages and bacteriocins. Pages 99-132 in: Genetics and Biochemistry of Pseudomonas. P. H. Clarke and M. H. Richmond, eds. John Wiley \& Sons, New York.

Howell, C. R., and Stipanovic, R. D. 1979. Control of Rhizoctonia solani on cotton seedlings with Pseudomonas fluorescens and with an antibiotic produced by the bacterium. Phytopathology 69:480-482

Jensen, E. C., Schrader, H. S., Rieland, B., Thompson, T. L., Lee, K. W., Nickerson, K. W., and Kokjohn, T. A. 1998. Prevalence of broadhost-range lytic bacteriophages of Sphaerotilus natans, Escherichia coli, and Pseudomonas aeruginosa. Appl. Environ. Microbiol. 64:575-580.

Keel, C., and G. Défago. 1997. Interactions between beneficial soil bacteria and root pathogens: Mechanisms and ecological impact. Pages $27-$ 46 in: Multitrophic Interactions in Terrestrial Systems. A. C. Gange and V. K. Brown, eds. Blackwell Science, London.

Keel, C., Schnider, U., Maurhofer, M., Voisard, C., Laville, J., Burger, U., Wirthner, P., Haas, D., and Défago, G. 1992. Suppression of root diseases by Pseudomonas fluorescens CHA0: Importance of the bacterial secondary metabolite 2,4-diacetylphloroglucinol. Mol. Plant-Microbe Interact. 5:4-13

Keel, C., Weller, D. M., Natsch, A., Défago, G., Cook, R. J., and Thomashow, L. S. 1996. Conservation of the 2,4-diacetylphloroglucinol biosynthesis locus among fluorescent Pseudomonas strains from diverse geographic locations. Appl. Environ. Microbiol. 62:552563

Kelln, R. A., and Warren, R. A. J. 1971. Isolation and properties of a bacteriophage lytic for a wide variety of pseudomonads. Can. J. Microbiol. 17:677-682.

Krylov, V. N., Dzhusupova, A. B., Akhverdyan, V. Z., Khrenova, E. A., Al'nikin, A. F., and Kopylova, Y. I. 1989. [Study of particle and structural morphology of Pseudomonas putida bacteriophage genomes for their classification]. Genetika 25:1559-1570. In Russian.

Laville, J., Voisard, C., Keel, C., Maurhofer, M., Défago, G., and Haas, D. 1992. Global control in Pseudomonas fluorescens mediating antibiotic synthesis and suppression of black root rot of tobacco. Proc. Natl. Acad. Sci. U.S.A. 89:1562-1566.

Levy, E., Gough, F. J., Berlin, K. D., Guiana, P. W., and Smith, J. T. 1992. Inhibition of Septoria tritici and other phytopathogenic fungi and bacteria by Pseudomonas fluorescens and its antibiotics. Plant Pathol.
41:335-341.

Lugtenberg, B. J. J., Dekkers, L., and Bloemberg, G. V. 2001. Molecular determinants of rhizosphere colonization by Pseudomonas. Annu. Rev. Phytopathol. 39:461-490.

Marsh, P., and Wellington, E. M. H. 1994. Phage host interactions in soil. FEMS (Fed. Eur. Microbiol. Soc.) Microbiol. Ecol. 15:99-108.

Maurhofer, M., Keel, C., Schnider, U., Voisard, C., Haas, D., and Défago, G. 1992. Influence of enhanced antibiotic production in Pseudomonas fluorescens strain CHA0 on its disease suppressive capacity. Phytopathology 82:190-195.

Middelboe, M. 2000. Bacterial growth rate and marine virus-host dynamics. Microb. Ecol. 40:114-124.

Miller, R. V. 2001. Environmental bacteriophage-host interactions: factors contribution to natural transduction. Antonie Leeuwenhoek 79:141-147.

Natsch, A., Keel, C., Pfirter, H. A., Haas, D., and Défago, G. 1994 Contribution of the global regulator gene gacA to persistence and dissemination of Pseudomonas fluorescens biocontrol strain CHA0 introduced into soil microcosm. Appl. Environ. Microbiol. 60:25532560.

O’Sullivan, M., Stephens, P. M., and O'Gara, F. 1990. Interactions between the soil-borne bacteriophage Fo-1 and Pseudomonas spp. on sugarbeet roots. FEMS (Fed. Eur. Microbiol. Soc.) Microbiol. Lett. 68:329-334.

Pantastico-Caldas, M., Duncan, K. E., Istock, C. A., and Bell, J. A. 1992. Population dynamics of bacteriophage and Bacillus subtilis in soil. Ecology 73:1888-1902.

Park, S. C., Shimamura, I., Fukunaga, M., Mori, K. I., and Nakai, T. 2000. Isolation of bacteriophages specific to a fish pathogen, Pseudomonas plecoglossicida, as a candidate for disease control. Appl. Environ. Microbiol. 66:1416-1422.

Ramette, A., Moënne-Loccoz, Y., and Défago, G. 2001. Polymorphism of the polyketide synthase gene phlD in biocontrol fluorescent pseudomonads producing 2,4-diacetylphloroglucinol and comparison of PhlD with plant polyketide synthases. Mol. Plant-Microbe Interact. 14:639652.

Sacherer, P., Défago, G., and Haas, D. 1994. Extracellular protease and phospholipase $\mathrm{C}$ are controlled by the global regulatory gene gacA in the biocontrol strain Pseudomonas fluorescens CHA0. FEMS (Fed. Eur Microbiol. Soc.) Microbiol. Lett. 116:155-160.

Sambrook, J., Fritsch, E. F., and Maniatis, T. 1989. Molecular Cloning: A Laboratory Manual, 2nd ed. Cold Spring Harbor Laboratory Press, Cold Spring Harbor, NY, U.S.A.

Schnider-Keel, U., Bang Lejbølle, K., Baehler, E., Haas, D., and Keel, C. 2001. The sigma factor AlgU(AlgT) controls exopolysaccharide production and tolerance towards desiccation and osmotic stress in the biocontrol agent Pseudomonas fluorescens CHA0. Appl. Environ. Microbiol. 67:5683-5693.

Scholl, D., Rogers, S., Adhya, S., and Merril, C. R. 2001. Bacteriophage K1-5 encodes two different tail fiber proteins, allowing it to infect and replicate on both $\mathrm{K} 1$ and $\mathrm{K} 5$ strains of Escherichia coli. J. Virol. 75:2509-2515.

Shaburova, O. V., Burkal'tseva, M. V., Pleteneva, E. A., and Krylov, V. N. 2000. Temperate bacteriophages for rhizospheric pseudomonads Pseudomonas putida: Isolation and comparative study. Russ. J. Genet. 36:753-756.

Shaburova, O. V., Kurochkina, L. P., and Krylov, V. N. 2001. Autoplaque formation in a Pseudomonas fluorescens strain: Phagelike particles and transactivation of the defective phage. Russ. J. Genet. 37:735-740.

Smit, E., Wolters, A. C., Lee, H., Trevors, J. T., and van Elsas, J. D. 1996. Interactions between a genetically marked Pseudomonas fluorescens strain and bacteriophage $\phi \mathrm{R} 2 \mathrm{f}$ in soil: Effects of nutrients, alginate encapsulation, and the wheat rhizosphere. Microb. Ecol. 31:125-140.

Stanisich, V. A., and Holloway, B. W. 1972. A mutant sex factor of Pseudomonas aeruginosa. Genet. Res. 19:91-108.

Stephens, P. M., O'Sullivan, M., and O'Gara, F. 1987. Effect of bacteriophage on colonization of sugarbeet roots by fluorescent Pseudomonas spp. Appl. Environ. Microbiol. 53:1164-1167.

Troxler, J., Azelvandre, P., Zala, M., Défago, G., and Haas, D. 1997a Conjugative transfer of chromosomal genes between fluorescent pseudomonads in the rhizosphere of wheat. Appl. Environ. Microbiol. 63:213-219.

Troxler, J., Berling, C.-H., Moënne-Loccoz, Y., Keel, C., and Défago, G. 1997b. Interactions between the biocontrol agent Pseudomonas fluores cens $\mathrm{CHA} 0$ and Thielaviopsis basicola in tobacco roots observed by immunofluorescence microscopy. Plant Pathol. 46:62-71.

van Regenmortel, M. H. V., Fauquet, C. M., Bishop, D. H. L., Carstens, E. B., Estes, M. K., Lemon, S. M., Maniloff, J., Mayo, M. A., McGeoch, 
D. J., Pringle, C. R., and Wickner, R. B. 2000. Virus Taxonomy. The Seventh Report of the International Committee on Taxonomy of Viruses. Academic Press, San Diego, CA, U.S.A.

Voisard, C., Bull, C., Keel, C., Laville, J., Maurhofer, M., Schnider, U., Défago, G., and Haas, D. 1994. Biocontrol of root diseases by Pseudomonas fluorescens CHA0: Current concepts and experimental approaches. Pages 67-89 in: Molecular Ecology of Rhizosphere Microorganisms. F. O'Gara, D. Dowling, and B. Boesten, eds. VCH Publishers, Weinheim, Germany.

Wang, C., Ramette, A., Punjasamarnwong, P., Zala, M., Natsch, A., Moënne-Loccoz, Y., and Défago, G. 2001. Cosmopolitan distribution of phlD-containing dicotyledonous crop-associated biocontrol pseudomo- nads of world-wide origin. FEMS (Fed. Eur. Microbiol. Soc.) Microbiol. Ecol. 37:105-116.

Waterbury, J. B., and Valois, F. W. 1993. Resistance to co-occurring phages enables marine Synechoccus communities to coexist with cyanophages abundant in seawater. Appl. Environ. Microbiol. 59:33933399.

Wiggins, B. A., and Alexander, M. 1985. Minimum bacterial density for bacteriophage replication: implications for significance of bacteriophages in natural ecosystems. Appl. Environ. Microbiol. 49:19-23.

Williams, S. T., Mortimer, A. M., and Manchester, L. 1987. Ecology of soil bacteriophages. Pages 157-179 in: Phage Ecology. S. H. Goyal, C. P. Gerba, and G. Bitton, eds. John Wiley \& Sons, Inc., New York. 